\title{
Antioxidant Assay of Bryophyllum gastonis bonnieri at Salt Stress
}

\author{
Preeti S.Kumarmath, Sharada.P \\ Department of Biotechnology \\ Basaveshwar Engineering College (Autonomous) Bagalkot.
}

\begin{abstract}
Bryophyllum gastonis bonnieri is a folk medicine as it consists of many antioxidants that protects against oxidative damage, and include compounds to remove or repair damaged molecules. The work is carried out for qualitative and quantitative phytochemical responses of plant to salt stress. When the plant is subjected to various strengths of $\mathrm{NaCl}(0,25,50,75 \& 100 \mathrm{mM})$ the growth of the plant is reduced due to stress induced. In salinity stress the plants responses by the accumulation of enzymatic antioxidants which react against the free radicals produced (Kanika Patel et al, 2011). Bryophyllum gastonis bonnieri subjected to $7,14,21$ and 28 days of salt stress has shown reduction in heightening of plant, amount of leaves and relative growth rate was reduced with increased in sodium chloride treatments. During salinity stress free radical level increased dramatically resulting in oxidative damage to cells. The plant overcame this damage by increased accumulation of antioxidants which neutralize free radicals.
\end{abstract}

Keywords: Bryophyllum, Antioxidants, Phytochemical, Oxidative, Salinity.

\section{Introduction}

Bryophyllum gastonis bonnieri is rich in alkaloids, flavonoids, phenolic compounds, tannins, saponins [1]. As per the various ethnopharmacological record of gastonis bonnieri, many research class have conducted studies to prove their pharmacological or biological properties. In addition, some researchers have carried out phytochemical studies that resulted in the findings of various types of secondary metabolites, along with different ingredients, especially from their leaves and aerial parts [2].

Salt stress is said to be a more unfavorable factor can minimize leaf water potential, which leads to less stiffness and some other reactions, and eventually lower crop productivity in arid and semi-arid zones. It is clear that plant salt stress tolerance needs the activation of complex metabolic activities including antioxidative pathways, particularly reactive oxygen species (ROS) and macrophage which contributes to continued growth under water stress [3]

Considering the destructive effect of salt stress on plants, one of the tasks for plant biologists is to find the ways that can develop salt tolerance in crop plants.
In fact, salt tolerance is a multigenic trait that governs different morphological and physiological factors [4]. Salt stress causes various physiological changes, like interruption of membranes, nutrient imbalance, change in detoxification of reactive oxygen species (ROS), differences in the activity of antioxidant enzymes and alteration in photosynthetic activity, and lowering of aperture of stomata [3,5]. Salt stress is one of the kind stress given to plant.

Salinity tolerance is directly related to scavenging capacity of biocatalyst, such as superoxide dismutase (SOD), catalase (CAT), glutathione peroxidase (GPX), ascorbate peroxidase (APX), and glutathione reductase (GR) and by collection of non-enzymatic antioxidant compounds [6,7]. Gill et al. and Tuteja et al. [8] the studies have revealed the presence of helicase proteins (e.g., DESD-box helicase and OsSUV3 dual helicase) functions during salt stress on plant showed modifying the photosynthetic and antioxidant machinery. Taking merits of the novel progress in the area of genomic, transcriptomic and metabolic methods. Life scientist are concentrating on the modified changes of a total countor of genes, proteins, and secondary metabolites that are accountable for different mechanisms during salt tolerance in different medicinal vegetation species.

\section{Materials and Methods}

\section{Selection of plants for salt stress studies}

The plants were divided into five groups and put through four individual salt stress $(25,50,75,100 \mathrm{mM})$ and one as control.

\section{Preparation of plant extract}

Fresh leaves are collected and crushed using different solvents like ethanol, chloroform and water. The crude solution was separated using whatmann filter paper and this filtrate was used for phytochemical findings.

\section{Preparation ofconcentrateforenzymaticantioxidants}

$2 \mathrm{~g}$ of fresh leaves are crushed with $3 \mathrm{ml}$ of phosphate buffer using pestle and mortar until slimy paste was obtained and paste is transferred to centrifuge tubes. The sample of interest is centrifuged at 10,000rpm for 10 minutes and upper supernatant solution was collected.

\section{Total phenolic content}

Aliquots of the extract were taken in glass tube and 
add $2.5 \mathrm{ml}$ of FCR reagent to the each test tubes. Then add $2 \mathrm{ml}$ of sodium bicarbonate to each test tube and make up the volume $10 \mathrm{ml}$ by adding the distilled water. A blue color was developed. The test solutions were warmed for a minute make it cold and optical density measured around 760nm.

\section{Total tannin content}

Aliquots of the extract were taken in glass tube and add $0.5 \mathrm{ml}$ of FD reagent to the each test tubes. Then add $1 \mathrm{ml}$ of sodium bicarbonate to each test tube and made up to $10 \mathrm{ml}$ by adding the pure water. The test solutions were kept for incubation for half an hour at room temperature. Optical density was measured at $760 \mathrm{~nm}$

\section{Enzyme activity assay \\ Enzyme assay :}

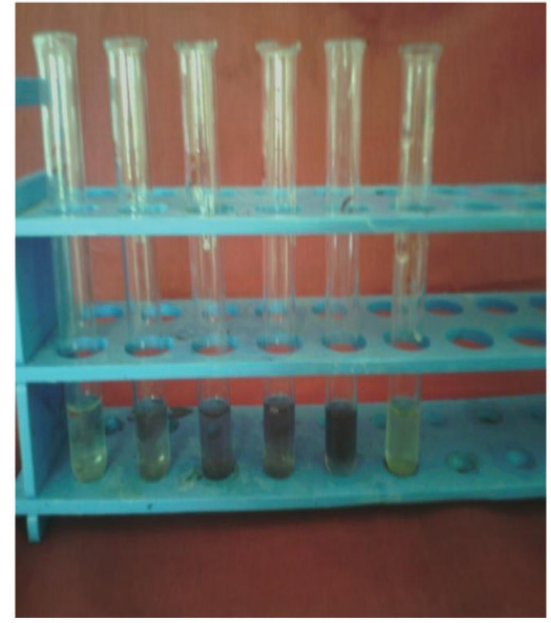

1 Control

2 sample 1

3 sample 2

4 sample 3

5 sample 4

6 Blank

Figure 1: SOD Activity

\section{SOD Activity}

SOD activity was determined by reduction in absorbance of superoxide nitro blue tetrazolium compound by the enzyme of reaction mixture containing $50 \mathrm{mM}$ potassium phosphate buffer $1580 \mu \mathrm{l}, 100 \mathrm{mM}$

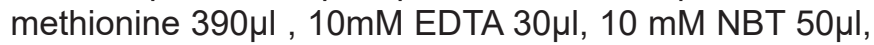
$1 \mathrm{M}$ Sodium bicarbonate $750 \mu \mathrm{l}, 200 \mu \mathrm{l}$ enzyme was taken in duplicates for all the samples. Control tubes were taken for experiment. Reaction starts by adding $10 \mathrm{mM}$ riboflavin $0.6 \mu \mathrm{l}$ and placing the tubes below a light source of florescent lamps for $15 \mathrm{~min}$. By switching

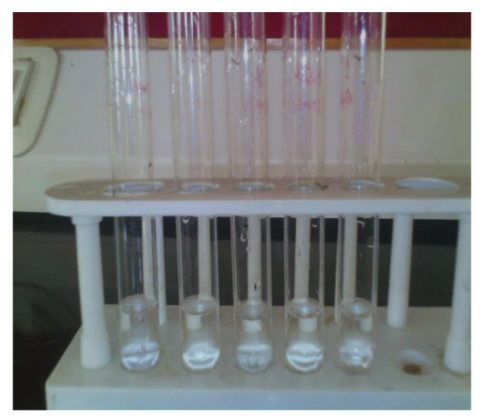

1 Control
2 sample 1
3 sample 2
4 sample 3
5 sample 4

Figure 2: Peroxidase Activity off the light and covering the tubes with black cloth the reaction was stopped. Tubes without enzyme developed maximal colour. The blank did not show any colour development. OD was recorded at $560 \mathrm{~nm}$ and one unit of enzyme activity was taken as the quantity of enzyme, which decreased the absorbance of the samples to 50 percent in comparison with blank tubes that was lacking enzymes.

SOD ACTIVTY $=($ Sample O.D/Control O.D $) \times 100=X$

\section{Peroxidase Activity}

Peroxidase activity was measured by taking buffer $\left(\mathrm{KH}_{2} \mathrm{PO}_{4}\right.$ buffer $\left.1.35 \mathrm{ml}, 50 \mathrm{mM}\right)$, Guicol $(0.4 \mathrm{ml}, 20 \mathrm{mM})$ and $0.2 \mathrm{ml}$ of enzyme extract $(3 \mathrm{ml})$. Reaction was started by adding hydrogen peroxide $(0.2 \mathrm{ml}, 10 \mathrm{mM})$ and $\mathrm{OD}$ was recorded at $470 \mathrm{~nm}$ for every 30 seconds.

POX ACTIVITY $=($ Total reaction mixture $\times 100) /$ $(6.39 \times 0.1 \times \Delta t)$

\section{Results and Discussion}

\section{Total Phenol Content}

On treatment of $\mathrm{Nacl}$ of varying concentration $(25 \mathrm{mM}, 50 \mathrm{mM}, 75 \mathrm{mM} \& 100 \mathrm{mM})$ at $7 \mathrm{th}, 14 \mathrm{th}, 21 \mathrm{st}$ and 28th days the content of phenol gradually increased.

\begin{tabular}{|l|l|l|l|l|}
\hline $\begin{array}{l}\mathrm{NaCl} \\
\text { concentration }\end{array}$ & $\boldsymbol{7}^{\text {th }} \mathbf{D A Y}$ & $\mathbf{1 4}^{\text {th }} \mathbf{D A Y}$ & $\mathbf{2 1}^{\text {st }} \mathbf{D A Y}$ & $\mathbf{2}^{\text {th }} \mathbf{D A Y}$ \\
\hline $\mathbf{\mu g m} / \mathrm{ml}$ & $\mu \mathrm{gm} / \mathrm{ml}$ & $\mu \mathrm{gm} / \mathrm{ml}$ & $\mu \mathrm{gm} / \mathrm{ml}$ \\
\hline $50 \mathrm{mM}$ & 850 & 910 & 920 & 970 \\
\hline $75 \mathrm{mM}$ & 980 & 930 & 950 & 1012 \\
\hline $100 \mathrm{mM}$ & 930 & 950 & 980 & 1108 \\
\hline
\end{tabular}

Table no 1: Effect of salt stress on Phenol content

Total Tannin Content

\begin{tabular}{|l|l|l|l|l|}
\hline NaCl concentration & $\begin{array}{l}7^{\text {th }} \text { day } \\
\mu \mathrm{g} / \mathrm{ml}\end{array}$ & $\begin{array}{l}14 \text { th day } \\
\mu \mathrm{g} / \mathrm{ml}\end{array}$ & $\begin{array}{l}21^{\text {st }} \\
\mu \mathrm{g} / \mathrm{ml}\end{array}$ & $\begin{array}{l}28^{\text {th }} \mathrm{day} \\
\mu \mathrm{g} / \mathrm{ml}\end{array}$ \\
\hline $25 \mathrm{mM}$ & 340 & 380 & 600 & 900 \\
\hline $50 \mathrm{mM}$ & 420 & 60 & 820 & 1200 \\
\hline $75 \mathrm{mM}$ & 420 & 740 & 980 & 1220 \\
\hline $100 \mathrm{mM}$ & 900 & 920 & 1200 & 1400 \\
\hline
\end{tabular}

Table no 2 : Effect of salt stress on Tannin content

\begin{tabular}{|c|c|c|c|c|}
\hline $\begin{array}{l}\mathrm{NaCl} \\
\text { concentration }\end{array}$ & $\begin{array}{l}\text { 7th DAY } \\
\mu \mathrm{mol} / \mathrm{mg} / \mathrm{ml}\end{array}$ & $\begin{array}{l}14^{\text {th }} \text { DAY } \\
\mu \mathrm{mol} / \mathrm{mg} / \mathrm{ml}\end{array}$ & $\begin{array}{l}21 \mathrm{st} \text { DAY } \\
\mu \mathrm{mol} / \mathrm{mg} / \mathrm{ml}\end{array}$ & $\begin{array}{l}28^{\text {th }} \mathrm{DAY} \\
\mu \mathrm{mol} / \mathrm{mg} / \mathrm{ml}\end{array}$ \\
\hline $25 \mathrm{mM}$ & 1.56 & 2.73 & 4.9 & 1.12 \\
\hline $50 \mathrm{mM}$ & 2.16 & 3.59 & 7.32 & 4.77 \\
\hline $75 \mathrm{mM}$ & 2.33 & 4.84 & 9.79 & 6.15 \\
\hline $100 \mathrm{mM}$ & 1.82 & 3.78 & 6.24 & 5.02 \\
\hline
\end{tabular}

Table no 3 : Effect of salt stress on SOD activity 


\begin{tabular}{|c|l|l|l|l|}
\hline $\begin{array}{c}\mathrm{NaCl} \\
\text { concentration }\end{array}$ & $\begin{array}{l}7^{\text {th }} \mathbf{D A Y} \\
\text { Units/ml }\end{array}$ & $\begin{array}{l}14^{\text {th }} \mathbf{D A Y} \\
\text { Units/ml }\end{array}$ & $\begin{array}{l}21^{\text {st }} \mathbf{D A Y} \\
\text { Units/ml }\end{array}$ & $\begin{array}{l}\mathbf{2 8}^{\text {th }} \mathbf{D A Y} \\
\text { Units/ml }\end{array}$ \\
\hline $25 \mathrm{mM}$ & 5.63 & 6.94 & 8.92 & 59.15 \\
\hline $50 \mathrm{mM}$ & 5.63 & 55.86 & 46.02 & 125.82 \\
\hline $75 \mathrm{mM}$ & 94.8 & 64.78 & 85.44 & 237.5 \\
\hline $100 \mathrm{mM}$ & 79.8 & 24.78 & 24.4 & 69.48 \\
\hline
\end{tabular}

Table no 4 : Effect of salt stress on Peroxidase activity

\section{Total Tannin Content}

On treatment of $\mathrm{Nacl}$ of varying concentration (25mM, 50mM, 75mM \& 100mM) at 7th, 14th, 21st and 28th days the content of tannin gradually increased.

\section{Enzyme assay:}

\section{SOD Activity}

There was gradual increase in SOD activity upto 21 st days later there was decrease in the activity after 22nd day of treatment, this was observed upto 28th days. Even the higher concentration of about $100 \mathrm{mM}$ $\mathrm{NaCl}$ showed decrease after 14th day of treatment of saline solution which suggested that high concentration of salinity will inactivate the SOD activity which was observed upto 28 days.

\section{Peroxidase Activity}

The peroxidase activity was increased upto 28 day of treatment with the varying concentration of $\mathrm{NaCl}$ (25mM, 50mM, 75mM \& 100mM) at 7th, 14th, 21st and 28th days, the activity of peroxidase enzyme increased gradually.

\section{Conclusion}

The metabolic pathways of plant as well as the structure gets effected. Salinity develops cellular adjustment with a significant understanding of cell structure and metabolism due to ionic and osmotic effects. Proteins show an important role in salt tolerance and cellular adaptation. There was proportionate increase in the accumulation of antioxidants as the salt stress was increased and there was slightly reduction in the growth of Bryophyllum gastonis bonnieri plant. Altogether, the observation done in various Phytochemical studies prove that medicinal plants reciprocate to salt stress.

\section{References}

1. D.E. Okwu, and C. Josiah,(2006). Evaluation of the chemical composition of two Nigerian medicinal plants. African Journal of Biotechnology, 5(4): 357361

2. Foulsham Gaind KN et al, (1976). Phenolic compounds from the leaves of Kalanchoe pinnata. Planta Med, 23(2):149-153
3. Bhaskar Gupta1 and Bingru Huang, (2014). Mechanism of Salinity Tolerance in Plants: Physiological, Biochemical, and Molecular Characterization. International Journal of Genomics

4. K. Apel and H. Hirt, (2004). Reactive oxygen species: metabolism, oxidative stress, and signal transduction. Annual Review of Plant Biology, vol. 55, pp. 373-399.

5. J. Rozema and T. Flowers, (2008). Ecology: crops for a salinized world. Science, vol. 322, pp. 14781480.

6. P. Ahmad and S. Umar, (2011). Oxidative Stress: Role of Antioxidants in Plants, Studium Press, New Delhi, India.

7. P. Ahmad and M. N. V. Prasad, (2012). Abiotic Stress Responses in Plants: Metabolism, Productivity and Sustainability, Springer, New York, NY, USA.

8. Narendra Tuteja, Sarvajeet Singh Gill, Renu Tuteja, (2011) Plant responses to abiotic stresses: Shedding light on salt, drought, cold and heavy metal stress. Bentham Science Publisher Ltd. Omics and plant abiotic stress tolrance, pp.39-64.

9. Ali EsmailAl-Snafi, (2013). The chemical constituents and pharmacological effects of Bryophyllum calycinum. International Journal of Pharma Science and Research vol 4: 171-176.

10. Arshad Naji Alhasnawi, Ahsan A Kadhimi, Anizan Isahak, Azhar Mohamad, Febri Doni and Wan Mohtar, (2014). Salinity stress in plant and An important antioxidant enzyme. Life Science Journal, Vol 11(10): 913-920.

11. Ezatollah Esfandiari, Fariborz Shekari, Farid Shekari and Manouchehr Esfandiari, (2007). The effect of salt stress on antioxidant enzymes activity and lipid peroxidation on the wheat seedlings. Plant Science vol 35: 48-56.

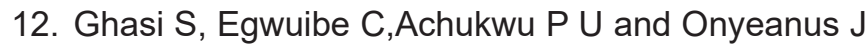
C, (2011). Assessment of the medical benefit in the folkloric use of Bryophyllum pinnatum leaf among the lobos of Nigeria for the treatment of hypertension. African Journal of pharmacy and pharmacology, vol 5(1): 83-92.

13. Jayachitra A and Krithiga N,(2012). Study on antioxidant property in selected medicinal plant extracts. International Journal of Medicine, vol 2: 495-500. 
14. Kanika Patel, Neelesh Kumar and Sharma N K,(2011). Pharmacognostic and Phytochemical evaluation of Bryophyllu pinnatum leaves. Journal of Advanced Scientific Research, vol 2(1): 42-49.

15. Nwali B U, Okaka A N C, Ibiam U A and Aja P M, (2012). Phytochemical composition of Bryophyllum pinnatum leaves", International Journal of Advanced Biological Research, vol 2(4): 614-616.

16. Quazi Majaz*, Molvi Khurshid, Sayyed Nazim, Khan Rahil and Shikh Siraj, (2011). Evaluation of antioxidant activity of Kalanchoe pinnata roots. International Journal of Research in Ayurveda and Pharmacy, vol 2(6): 1772-1775.

17. Seema V Pattewar, (2012). Kalanchoe pinnata: Phytochemical and Pharmacological profile. International Journal of Phytopharmacy, vol 2(1): 1-8.
18. Umebese C E and Falana F D, (2013). Growth, phytochemicals and antifungal activity of Bryophyllum pinnatum L. subjected to water deficit stress. African Journal of Biotechnology, vol 12(47): 6599-6604.

19. Weria Weisany, Yousef Sohrabi, Gholamreza Heidari, Adel Siosemardeh and Kazem Ghassemi Golezani, (2012). Changes in antioxidant enzymes activity and plant performance by salinity stress and zinc application in soybean. Plant Omics Journal, vol 5(2): 60-67.

20. Yadav RNS and Munin Agarwala, ,(2011). Phytochemical analysis of some medicinal plants. Journal of Phytology, vol 3(12): 10-14. 